\title{
ASPEK HUKUM PENAWARAN UMUM EFEK SECARA ELEKTRONIK
}

\author{
Niken Previanti \\ Fakultas Hukum, Universitas Brawijaya \\ email: kenprev@gmail.com
}

disampaikan 9/8/2020 - di-review 23/9/2020 - diterima 31/5/2021

DOI: $10.25123 /$ vej.v7i1.4248

\begin{abstract}
The main issue discussed here, using a juridical normative method, regards the legal validity and implementation of, and legal protection given to investors, found in the Financial Services Authority Regulation No. 41/POJK.04/2020 re. Electronic Public Offering of Equity, Debt Securities and/or Syaria' Undivided Share. Important to note is the fact that the Financial Services Authority is established by virtue of Law No. 21 of 2011 to replace and take over the functions of the Capital Market and Financial Institution Supervisory Agency and the Central Bank in regulating and supervising Indonesian Banks and Capital Markets and lastly protect consumers in the financial services industry. Here should also mentioned the fact that the Capital Market Law (No. 8/1995) and its implementing regulations has yet to respond to how advances in information technology can be utilized to regulate-control and supervise public offering of shares or equity in the Capital Market.
\end{abstract}

Keywords:

Financial Services Authority, electronic public offering, legal protection of investors.

\begin{abstract}
Abstrak
Persoalan utama yang ditelaah di sini, dengan menggunakan metoda yuridis normatif, berkaitan dengan keberlakuan, pelaksanaan dan pengaturan perlindungan hukum bagi pemodal dalam Peraturan Otoritas Jasa Keuangan No. 41/POJK.04/2020 tentang Pelaksanaan Kegiatan Penawaran Umum Efek Bersifat Ekuitas, Efek Bersifat Utang, dan/atau Sukuk Secara Elektronik. OJK sendiri dibentuk berdasarkan UU Nomor 21 Tahun 2011 dan didirikan untuk menggantikan peran Badan Pengawas Pasar Modal dan Lembaga Keuangan (Bappepam-LK) dalam pengaturan dan pengawasan pasar modal dan lembaga keuangan, serta menggantikan peran Bank Indonesia dalam pengaturan dan pengawasan bank, serta untuk melindungi konsumen industri jasa keuangan. Dicermati pula UU Pasar Modal (No. 8/1995) maupun Peraturan Pelaksanaannya belum mengatur hal ikhwal bagaimana kecanggihan teknologi informasi dapat dimanfaatkan untuk mengaturmengendalikan dan mengawasi lalulintas penawaran efek-saham di Indonesia
\end{abstract}

Kata Kunci:

OJK, penawaran umum efek elektronik, perlindungan hukum bagi pemodal.

\section{Pendahuluan}

Pasar modal memiliki peranan penting bagi perekonomian Indonesia. Berdasarkan bagian penjelasan Undang-Undang Republik Indonesia Nomor 8 Tahun 1995 tentang Pasar Modal (selanjutnya disebut "UUPM"), diketahui bahwa pasar modal memiliki tujuan untuk menunjang pembangunan nasional, dengan tujuan akhirnya adalah kesejahteraan rakyat Indonesia. Pasar modal menjadi 
tempat bertemunya pihak yang kekurangan atau membutuhkan modal usaha (selanjutnya disebut "Emiten"1), dengan pihak yang memiliki kelebihan dana (selanjutnya disebut "pemodal").

Dalam rangka mendukung penguatan pasar modal di Indonesia, maka perlu adanya peningkatan efisiensi, efektivitas, transparansi, dan akuntabilitas dalam pelaksanaan penawaran umum di pasar modal. Penawaran umum merupakan salah satu kegiatan penting dalam pasar modal. Berdasarkan ketentuan Pasal 1 angka 1 UUPM, yang dimaksud dengan penawaran umum adalah kegiatan penawaran efek yang dilakukan oleh Emiten untuk menjual efek kepada masyarakat atau pemodal berdasarkan tata cara yang diatur dalam UUPM dan peraturan pelaksanaannya (selanjutnya disebut "Penawaran Umum"). Peningkatan proses Penawaran Umum tersebut bertujuan untuk memberikan manfaat lebih bagi para pihak yang terlibat dalam pasar modal, serta menghimpun kepercayaan publik untuk melakukan investasi di pasar modal Indonesia.

Penawaran Umum pada dasarnya dilakukan di pasar perdana. Pasar perdana (primary market) merupakan tempat ditransaksikan efek atau sekuritas untuk pertama kali sebelum efek tersebut dicatatkan di bursa efek. ${ }^{2}$ Menurut Sunariyah dalam Pengantar Pengetahuan Pasar Modal, pasar perdana memiliki pengertian sebagai tempat penjualan surat berharga baru dari perusahaan (emiten) kepada masyarakat melalui sindikasi penjaminan, sebelum surat berharga tersebut diperdagangkan di Bursa Efek. Di pasar perdana inilah pihak Emiten menawarkan efek kepada masyarakat umum atau pemodal untuk pertama kalinya, oleh karena itu kegiatan di pasar perdana disebut dengan penawaran umum (Initial Public Offering/IPO).

Otoritas Jasa Keuangan (selanjutnya disebut "OJK"), selaku lembaga yang berwenang melakukan pembinaan, pengaturan, dan pengawasan sehari-hari kegiatan pasar modal, berpendapat bahwa perlu adanya penguatan terhadap pelaksanaan Penawaran Umum. Penguatan ini dimaksudkan untuk menggalang dana lebih banyak di sektor pasar modal Indonesia. Dalam konferensi pers

\footnotetext{
Emiten dalam tulisan ini juga memiliki arti sebagai pihak yang melakukan Penawaran Umum.

Mas Rahmah, Hukum Pasar Modal, Kencana, Jakarta, 2019, hlm., 139.
} 
Perkembangan Kebijakan Kondisi Terkini Sektor Jasa Keuangan pada 4 Agustus 2020, Ketua Dewan Komisioner OJK, Wimboh Santoso, mengatakan bahwa hingga 28 Juli 2020 penghimpunan dana di pasar modal sebesar Rp54,1 triliun, dengan 28 Emiten baru, yang mana hasil tersebut menunjukkan ada penurunan. OJK mencatat adanya penurunan minat penghimpunan dana melalui Penawaran Umum, baik secara jumlah maupun nilai. Pada Juli 2019, total Penawaran Umum adalah sebanyak 94 dengan nilai Rp109,18 triliun, sementara itu pada Juli 2020 jumlah Penawaran Umum sebanyak 73 dengan nilai Rp54,13 triliun. ${ }^{3}$ Penurunan minat pemodal tentu menjadi permasalahan serius bagi perekonomian.

Model dari pelaksanaan Penawaran Umum menjadi faktor yang menurut OJK tidak mendukung peningkatan partisipasi pemodal. Beberapa catatan penting terhadap model pelaksanaan Penawaran Umum saat ini adalah perlunya kemudahan pemesanan efek, perlunya peningkatan alokasi efek untuk penjatahan terpusat, proses bisnis Penawaran Umum untuk penjatahan terpusat yang masih manual dan relatif sulit diakses, tidak tersedianya efek yang memadai bagi pemodal publik, serta perlunya peningkatan akuntabilitas dan transparansi dalam penentuan harga penawaran efek dan penentuan jumlah efek. ${ }^{4}$ Dengan adanya perkembangan teknologi informasi yang memberikan kemudahan bagi masyarakat untuk mengakses informasi dan melakukan transaksi keuangan, maka dirasa perlu untuk melakukan pengembangan terhadap sistem Penawaran Umum di Indonesia.

Pada tanggal 1 Juli 2020 OJK menetapkan Peraturan Otoritas Jasa Keuangan Nomor 41/P0JK.04/2020 tentang Pelaksanaan Kegiatan Penawaran Umum Efek Bersifat Ekuitas, Efek Bersifat Utang, dan/atau Sukuk secara Elektronik (selanjutnya disebut "POJK 41/2020"). POJK 41/2020 diharapkan dapat mengatasi permasalahan yang timbul dalam proses Penawaran Umum. Berdasarkan Ringkasan POJK 41/2020, ketentuan ini hadir untuk meningkatkan

3 CNBC Indonesia, Ternyata ini yang Menjadi Penyebab Pasar Modal RI Kian stabil, https://www.cnbcindonesia.com/market/20200807124040-17-178199/ternyata-ini-yangjadi-penyebab-pasar-modal-ri-kian-stabil,_diakses 13 September 2020 pukul 14.20WIB.

4 Bagian Penjelasan Peraturan Otoritas Jasa Keuangan Nomor 41/POJK.04/2020 tentang Pelaksanaan Kegiatan Penawaran Umum Efek Bersifat Ekuitas, Efek Bersifat Utang, dan/atau Sukuk secara Elektronik. 
ketersebaran pemodal, meningkatkan jumlah pemodal publik, dan untuk meningkatkan akuntabilitas serta transparansi dalam penentuan harga Penawaran Umum perdana dan mekanisme penjatahan dalam Penawaran Umum dengan menerapkan teknologi informasi dalam proses bookbuilding dan penawaran efek dalam Penawaran umum. ${ }^{5}$

Hadirnya POJK 41/2020 menimbulkan perubahan terhadap proses Penawaran Umum di Indonesia. Penawaran Umum secara elektronik yang diusung POJK 41/2020 merupakan bentuk Penawaran Umum yang dikembangkan dengan teknologi informasi (elektronik), dan memiliki sarana (sistem) dan mekanisme yang berbeda dengan Penawaran Umum sebelumnya (cenderung manual).

Berdasarkan pada latar belakang tersebut, maka tulisan ini bermaksud untuk memberikan penjabaran tentang aspek hukum dari Penawaran Umum atas efek, yang dilakukan secara elektronik. Dimulai dengan kedudukan POJK 41/2020 sebagai dasar hukumnya, pengaturan pelaksanaannya, serta perlindungan hukum khususnya bagi pemodal yang terlibat di dalamnya. Semua aspek tersebut ditinjau berdasarkan POJK 41/2020, peraturan perundang undangan yang berlaku di bidang pasar modal serta peraturan terkait lainnya.

Tulisan ini merupakan hasil penelitian yuridis normatif. Penelitian yuridis normatif merupakan metode penelitian yang menggunakan kajian terhadap norma-norma yang ada untuk menyelesaikan permasalahan yang diangkat dalam sebuah penelitian. Adapun pendekatan dari penelitian ini adalah pendekatan perundang-undangan (statute approach), yang dilakukan dengan menelaah semua peraturan perundang-undangan yang berkaitan dengan isu hukum yang ditangani. 6

5 Ringkasan Peraturan Otoritas Jasa Keuangan Nomor 41/POJK.04/2020 tentang Pelaksanaan Kegiatan Penawaran Umum Efek Bersifat Ekuitas, Efek Bersifat Utang, dan/atau Sukuk secara Elektronik.

6 Peter Mahmud Marzuki, Penelitian Hukum (Edisi Revisi), Kencana, Jakarta, 2015, hlm. 133. 


\section{Pembahasan}

\section{Kedudukan P0JK 41/2020 sebagai Dasar Hukum Penawaran Umum secara Elektronik}

Perlu disadari bahwa hukum harus mampu mengikuti perkembangan jaman. Dalam hal ini, hukum harus bisa mengakomodir perkembangan dunia usaha secara global. Studi tentang hubungan hukum dan pembangunan ekonomi menunjukkan bahwa pembaruan ekonomi tidak berhasil tanpa pembaruan hukum. ${ }^{7}$ Penawaran Umum secara elektronik tidak diatur dalam UUPM maupun peraturan pelaksanaannya.Oleh karena itu, demi tercapainya kepastian hukum dalam pelaksanaan Penawaran Umum secara elektronik maka OJK merasa perlu menetapkan POJK 41/2020.

Pengaturan Penawaran Umum secara elektronik dalam POJK 41/2020 menimbulkan pertanyaan apakah Peraturan OJK cukup menjadi dasar hukum penerapan Penawaran Umum secara elektronik. Melihat hal tersebut, maka perlu dikaji kembali kedudukan OJK sebagai lembaga independen yang berwenang melakukan pengaturan dan pengawasan kegiatan pasar modal di Indonesia.

Undang-Undang Republik Indonesia Nomor 21 Tahun 2011 tentang Otoritas Jasa Keuangan (selanjutnya disebut "UUOJK") membawa perubahan terhadap struktur kelembagaan pasar modal. Perubahan tersebut khususnya berkaitan dengan lembaga yang berwenang melakukan pembinaan, pengaturan, dan pengawasan kegiatan pasar modal di Indonesia. UUOJK memberikan kewenangan kepada OJK untuk melakukan pengaturan dan pengawasan kegiatan pasar modal. ${ }^{8}$ Berdasarkan amanat UUOJK, pada 31 Desember 2012 pengawasan kegiatan pasar modal beralih kepada OJK 9 .

OJK sebagai lembaga independen dalam melakukan tugas dan wewenangnya, bebas dari campur tangan pihak lain, diharapkan dapat membawa

7 Rochani Urip Salami, Hukum Pasar Modal dan Tanggung Jawab Sosial, Jurnal Dinamika Hukum Vol. 11 No. 3, September 2011, Fakultas Hukum Universitas Jenderal Soedirman, hlm. 441.

8 Pasal 6 Undang-Undang Republik Indonesia Nomor 21 Tahun 2011 tentang Otoritas Jasa Keuangan.

9 Sebelumnya kewenangan pengaturan dan pengawasan kegiatan pasar modal di Indonesia dilakukan oleh Badan Pengawas Pasar Modal dan Lembaga Keuangan/Bapepam LK berdasarkan UUPM. 
pasar modal Indonesia menjadi lebih independen dan terintegrasi dengan lembaga keuangan lainnya. Hal tersebut dikarenakan selain melakukan pengaturan dan pengawasan kegiatan pasar modal, OJK juga memiliki tugas dan wewenang untuk melakukan pengaturan dan pengawasan yang terintegrasi terhadap keseluruhan kegiatan dalam sektor jasa keuangan ${ }^{10}$. Lebih detil lagi bahwa OJK dibentuk dengan tujuan:11 (i) keseluruhan kegiatan di sektor jasa keuangan dapat terselenggara secara tertaur, adil, transparan, dan akuntabel; (ii) mampu melindungi kepentingan konsumen dan masyarakat yang diwujudkan dalam sistem pengaturan dan pengawasan yang terintegrasi terhadap seluruh kegiatan sektor jasa keuangan.

Pembuatan Peraturan OJK merupakan salah satu wewenang yang diberikan oleh UUOJK kepada OJK. Dalam ketentuan Pasal 8 UUOJK dinyatakan bahwa OJK dalam melaksanakan tugas pengaturannya di sektor jasa keuangan memiliki wewenang untuk menetapkan peraturan perundang-undangan di sektor jasa keuangan (Pasal 8 huruf b UUOJK), serta menetapkan peraturan dan keputusan OJK (Pasal 8 huruf c UUOJK). Berdasarkan ketentuan tersebut dan mengingat bahwa pasar modal merupakan salah satu sektor yang menjadi ranah pengawasan dan pengaturan $\mathrm{OJK}$, maka menjadi hal yang wajar apabila OJK membuat dan menetapkan peraturan baru di sektor pasar modal untuk menjamin kepastian hukum dalam kegiatan pasar modal di Indonesia.

Di sisi pasar modal, secara umum kegiatan Penawaran Umum mengacu pada ketentuan Bab IX UUPM tentang Emiten dan Perusahaan Publik (Pasal 70 Pasal 84 UUPM), dan pelaksanaannya diatur dalam beberapa Peraturan Bapepam LK (yang masih berlaku), Peraturan OJK, serta Surat Edaran OJK. Berdasarkan pada ketentuan Pasal 70 ayat (4) UUOJK, diketahui bahwa ketentuan dalam UUPM serta peraturan pelaksanaannya masih dinyatakan tetap berlaku sepanjang tidak bertentangan dengan dan belum diganti berdasarkan UUOJK. oleh karena itu,

10 Pasal 6 Undang-Undang Republik Indonesia Nomor 21 Tahun 2011 tentang Otoritas Jasa Keuangan menyatakan bahwa 0JK melaksanakan tugas pengaturan dan pengawasan terhadap kegiatan jasa keuangan di sektor Perbankan, Pasar Modal, Perasuransian, Dana Pensiun, Lembaga Pembiayaan, dan Lembaga Jasa Keuangan lainnya.

11 Andrian Sutedi, Aspek Hukum Otoritas Jasa Keuangan, Raih Asa Sukses, Jakarta, 2014, hlm. 57. 
selama OJK berdasarkan kewenangannya tidak melakukan perubahan atau penggantian ketentuan yang terkandung dalam UUPM dan aturan pelaksanaannya, maka ketentuan pasar modal dalam UUPM dan aturan pelaksanaannya tersebut masih berlaku.

Melengkapi penjelasan di atas, bahwa OJK menerapkan dua asas penting dalam melaksanakan tugas dan wewenangnya terutama berkaitan dengan pembuatan peraturan OJK, yaitu: ${ }^{12}$

1. Asas independensi, yang artinya bahwa OJK independen dalam pengambilan keputusan dan pelaksanaan fungsi, tugas, dan wewenangnya, dengan tetap sesuai dengan peraturan perundang-undangan yang berlaku; dan

2. Asas kepastian hukum, yang artinya bahwa OJK, sebagai lembaga di dalam negara hukum, mengutamakan landasan peraturan perundang-undangan dan keadilan dalam setiap kebijakan penyelenggaraan kegiatan OJK.

Berdasarkan kedua asas tersebut di atas, maka peraturan perundang-undangan yang berlaku di Indonesia wajib menjadi rambu-rambu, batasan atau dasar pertimbangan bagi OJK dalam melaksanakan tugas dan wewenangannya, khususnya dalam membuat peraturan OJK.

Merupakan hal yang wajar bila OJK mempertimbangkan UUPM beserta peraturan pelaksanaannya yang masih berlaku, sebagai dasar pembuatan POJK 41/2020. Hal tersebut sebagaimana terlihat dalam bagian "mengingat" dalam POJK 41/2020, diketahui bahwa UUPM dan UUOJK adalah dua Undang-Undang yang menjadi dasar dibentuknya POJK 41/2020. Dalam ketentuan Pasal 11 POJK 41/2020,dinyatakan bahwa Emiten yang melakukan kegiatan Penawaran Umum secara elektronik memiliki kewajiban untuk mengikuti ketentuan peraturan perundang-undangan di bidang pasar modal mengenai tata cara pendaftaran dalam rangka Penawaran Umum serta pemesanan dan penjatahan Efek dalam Penawaran Umum, kecuali telah diatur dalam POJK 41/2020.

Kedudukan POJK dalam peraturan perundang-undangan dijamin dalam Undang-Undang Nomor 12 Tahun 2011 tentang Pembentukan Peraturan

12 Bagian Umum Penjelasan Undang-Undang Republik Indonesia Nomor 21 Tahun 2011 tentang Otoritas Jasa Keuangan. 
Perundang-Undangan (selanjutnya disebut "UUP3U"). Pasal 8 UUP3U menyatakan bahwa peraturan perundang-undangan termasuk peraturan yang ditetapkan oleh lembaga yang dibentuk oleh undang-undang, dan OJK termasuk dalam kriteria tersebut. Peraturan perundang-undangan yang ditetapkan oleh OJK tersebut (dalam hal ini peraturan OJK), diakui keberadaannya dan memiliki kekuatan hukum yang mengikat.

Berdasarkan penjelasan di atas, maka menurut penulis POJK 41/2020 tepat menjadi dasar hukum dari Penawaran Umum secara elektronik. Hal ini dikarenakan OJK pada dasarnya memiliki kewenangan untuk membuat peraturan baru di bidang pasar modal. Pembuatan POJK 41/2020 memang diperlukan karena adanya pengembangan terhadap proses pelaksanaan Penawaran Umum yang tidak diatur dalam UUPM maupun peraturan pelaksanaannya.

Bila dirinci kembali, maka dasar hukum Penawaran Umum secara elektronik dalah POJK 41/2020, peraturan pelaksanaan dari POJK 41/2020, peraturan Self Regulatory Organization/SRO yang ditunjuk OJK, serta peraturan perundang-undangan di sektor pasar modal berkaitan dengan Penawaran Umum. Peraturan perundang-undangan di sektor pasar modal tersebut berkaitan dengan ketentuan terkait pelaksanaan Penawaran Umum yang memang ditunjuk oleh POJK 41/2020 untuk tetap dilaksanakan, atau ketentuan yang tidak diatur dalam POJK 41/2020 (maupun peraturan pelaksanaannya).

\section{Penawaran Umum secara Elektronik berdasarkan POJK 41/2020}

Penawaran Umum secara elektronik ditandai dengan hadirnya sistem yang disebut Sistem Penawaran Umum Elektronik (selanjutnya disebut "Sistem e-IPO"). Berdasarkan ketentuan Pasal 1 angka 5 POJK 41/2020, Sistem e-IPO merupakan sistem teknologi informasi dan/atau sarana yang digunakan untuk melaksanakan kegiatan dalam Penawaran Umum. Sistem e-IPO wajib mencakup semua kegiatan dalam Penawaran Umum dan harus menghasilkan laporan berkaitan dengan kegiatan Penawaran Umum tersebut (Pasal 12 P0JK 41/2020). Adapun kegiatan 
Penawaran Umum dalam Sistem e-IPO paling sedikit meliputi Penawaran Awal ${ }^{13}$ (bookbuilding), penawaran Efek ${ }^{14}$ (offering), Penjatahan Efek, dan penyelesaian pemesanan atas Efek.

BEI dalam press release-nya menyatakan bahwa Sistem e-IPO dibuat dengan tujuan untuk menyediakan akses untuk berpartisipasi dalam Penawaran Umum yang mudah dijangkau oleh seluruh pemodal dan Perusahaan Efek ${ }^{15}$. Hal tersebut khususnya dalam tahap penyampaian permintaan pada masa penawaran awal dan tahap penyampaian pesanan saham perdana pada masa Penawaran Umum. Sistem e-IPO ini memiliki tujuan memperluas partisipasi Perusahaan Efek sebagai agen penjualan (selling agent) dalam proses Penawaran Umum. Sistem eIPO juga diharapkan dapat meningkatkan partisipasi penyebaran kepemilikan saham khususnya bagi pemodal ritel pada Pasar Perdana, sehingga diharapkan dapat meningkatkan likuiditas perdagangan saham di Pasar Sekunder. ${ }^{16}$

Sistem e-IPO disediakan oleh pihak yang ditunjuk OJK dan disebut dengan Penyedia Sistem ${ }^{17}$. Penyedia Sistem merupakan fungsi baru dalam Penawaran Umum. Sebagai tindak lanjut atas POJK 41/2020, OJK menerbitkan Keputusan Dewan Komisioner Otoritas Jasa Keuangan Nomor Kep-45/D.04/2020 tentang Penunjukkan PT Bursa Efek Indonesia, PT Kliring Penjamin Efek Indonesia, dan PT Kustodian Sentral Efek Indonesia sebagai Penyedia Sistem e-IPO. Pihak-pihak tersebut merupakan pihak yang telah dikenal sebelumnya dalam proses Penawaran Umum, namun dengan adanya POJK 41/2020 pihak-pihak tersebut

13 Penawaran Awal adalah ajakan baik langsung atau tidak langsung dengan menggunakan Prospektus Awal yang bertujuan untuk mengetahui minat calon pembeli atas Efek yang akan ditawarkan dan/atau perkiraan harga penawaran Efek (Pasal 1 angka 13 POJK 41/2020).

14 Efek adalah surat berharga, yaitu surat pengakuan utang, surat berharga komersial, saham, obligasi, tanda bukti utang, unit penyertaan kontrak investasi kolektif, kontrak berjangka panjang atas efek, dan setiap derivatif efek (Pasal 1 angka 2 POJK 41/2020).

15 Perusahaan Efek adalah pihak yang melakukan kegiatan usaha sebagai Penjamin Emisi Efek, perantara pedagang Efek, dan/atau manajer investasi (Pasal 1 angka 16 POJK 41/2020).

16 Bursa Efek Indonesia, SRO akan Luncurkan Sistem e-IPO dan Indeks IDX Quality30, Press Release BEI No. 066/BEI.SPR/07-2020 tanggal 29 Juli 2020, https://www.idx.co.id/berita/press-release-detail/?emitenCode=1344, diakses 13 September 2020 pukul 19.38 WIB.

17 Penyedia Sistem adalah pihak yang ditunjuk oleh Otoritas Jasa Keuangan untuk menyediakan dan mengelola Sistem Penawaran Umum Elektronik (POJK 41/2020 Pasal 1 angka 6). 
memiliki kewajiban tambahan yang harus dilaksanakan dalam pelaksanaan Sistem e-IPO.

Secara garis besar, kewajiban Penyedia Sistem yang diatur dalam Pasal 2 ayat (3) POJK 41/2020 adalah untuk menyediakan, mengoperasikan, dan mengelola Sistem e-IPO. Termasuk di dalamnya adalah bertanggung jawab atas semua proses dan keamanan jalannya Sistem e-IPO. Penyedia Sistem berperan penting dalam melakukan kontrol dan menjamin kelancaran pelaksanaan dari Penawaran Umum menggunakan Sistem e-IPO. Karena terdiri dari beberapa lembaga dengan fungsi dan kewenangannya masing-masing, maka perlu adanya penjagaan atas keharmonisan dari lembaga-lembaga tersebut.

PT Bursa Efek Indonesia (selanjutnya disebut "BEI") sebagai salah satu Penyedia Sistem, diberi kewenangan oleh POJK 41/2020 untuk membangun dan mengelola Sistem e-IPO serta menyediakan situs web berkaitan dengan pelaksanaan Penawaran Umum secara elektronik. ${ }^{18}$ Pada tanggal 10 Agustus 2020, BEI dan OJK melakukan soft launching atas sistem Electronic Indonesia Public Offering atau Sistem e-IPO. Sistem e-IPO akan diuji coba hingga akhir tahun 2020 untuk kemudian dapat mulai dipergunakan secara aktif pada tahun 2021. Dengan adanya Sistem e-IPO ini, pemodal yang bermaksud membeli saham Pasar Perdana dapat langsung mengakses situs https://www.e-ipo.co.id atau melalui Partisipan Sistem dari Sistem-IPO yang telah terdaftar.

Sama halnya dengan Penyedia Sistem, Partisipan Sistem ${ }^{19}$ juga merupakan fungsi baru dalam Penawaran Umum. Partisipan Sistem mempergunakan Sistem e-IPO untuk menyampaikan minat dan/atau pesanan pada Penawaran Awal dan/atau penawaran Efek. Berkaitan dengan Partisipan Sistem, pada tanggal 10 Agustus 2020, BEI mengeluarkan Surat Keputusan Direksi PT Bursa Efek Indonesia No. Kep-00051/BEI/08-2020 perihal Pedoman Partisipan Sistem dalam Menggunakan Sistem Electronic Indonesia Public Offering yang Disediakan oleh PT

18 Pasal 3 huruf a dan c Peraturan Otoritas Jasa Keuangan Nomor 41/P0JK.04/2020 tentang Pelaksanaan Kegiatan Penawaran Umum Efek Bersifat Ekuitas, Efek Bersifat Utang, dan/atau Sukuk secara Elektronik.

19 Partisipan Sistem adalah Perusahaan Efek yang telah memiliki izin usaha dari OJK atau pihak lain yang disetujui OJK dan mempunyai hak untuk mempergunakan Sistem Penawaran Umum Elektronik (POJK 41/2020 Pasal 1 angka 7). 
Bursa Efek Indonesia (selanjutnya disebut "SKBEI 51/2020"). Hal tersebut berkaitan dengan kewajiban BEI sebagai salah satu Penyedia Sistem berdasarkan POJK 41/2020, untuk menyediakan pedoman penggunaan atas Sistem e-IPO. Secara garis besar SKBEI 51/2020 berisi tentang Ketentuan Umum Operasional Sistem e-IPO; Persyaratan dan Prosedur menjadi Partisipan Sistem; Hak dan Kewajiban Partisipan Sistem; Prosedur Penyampaian Minat, Pesanan dan Penyediaan Dana oleh Partisipan Sistem; Prosedur Pelaksanaan Penjaminan atas Penjatahan Pasti dan Penjatahan Terpusat; Prosedur Penggunaan Sarana Integrasi Sistem e-IPO; dan Prosedur Penanganan Gangguan Teknis pada Sistem e-IPO.

Masuk pada ketentuan mengenai Sistem e-IPO, Pasal 10 ayat (3) POJK 41/2020 mengatur, bahwa tidak semua jenis Efek pelaksanaan Penawaran Umum-nya dapat menggunakan Sistem e-IPO. Adapun jenis Efek yang Penawaran Umum-nya dapat menggunakan Sistem e-IPO meliputi: 1) Penawaran Umum Efek bersifat ekuitas ${ }^{20}$; 2) Penawaran Umum Efek bersifat utang dan/atau Sukuk ${ }^{21}$; dan 3) Penawaran Umum lain yang telah ditetapkan oleh 0JK. Melihat pada poin 3, diketahui bahwa ke depannya OJK masih membuka peluang untuk Efek jenis lain untuk dapat menggunakan Sistem e-IPO selama ditetapkan lebih lanjut oleh OJK.

Selain berkaitan dengan jenis Efek, Pasal 10 ayat (1) POJK 41/2020 juga memberikan batasan, bahwa Emiten wajib menggunakan Sistem e-IPO jika:

1. Emiten melakukan Penawaran Umum dengan menggunakan jasa Penjamin Emisi Efek22; dan

2. Efek yang ditawarkan Emiten melalui Penawaran Umum akan dicatatkan pada Bursa Efek.

20 Efek yang bersifat ekuitas adalah Efek yang berupa saham, atau Efek yang dapat ditukar dengan saham, atau Efek yang mengandung hak untuk memperoleh saham. https://www.idx.co.id/footer-menu/tautan-langsung/daftar-istilah/\#glossaryE, diakses 15 September 2020 pukul 23.25 WIB.

21 Sukuk adalah Efek syariah berupa sertifikat atau bukti kepemilikan yang bernilai sama dan mewakili bagian yang tidak terpisahkan atau tidak terbagi (syuyu'/ undividedshare), atas aset yang mendasarinya.

22 Penjamin Emisi Efek adalah pihak yang membuat kontrak dengan Emiten untuk melakukan Penawaran Umum bagi kepentingan Emiten dengan atau tanpa kewajiban untuk membeli sisa Efek yang tidak terjual (Pasal 1 angka 15 POJK 41/2020). 
Umumnya dan secara ringkas, tahapan Penawaran Umum terbagi atas tahapan sebagai berikut: ${ }^{23}$

1. Pra Penawaran Umum.

Pada tahapan ini pihak Emiten atau internal perusahaan akan melakukan beberapa hal meliputi: image building dan house clearing; due diligence; persetujuan Rapat Umum Pemegang Saham untuk go-public; perubahan anggaran dasar perusahaan; penunjukan penjamin emisi, lembaga penunjang, dan profesi penunjang; persipan dokumen; konfirmasi agen penjual; kontrak pendahuluan dengan bursa; dan penyampaian Pernyataan Pendaftaran ${ }^{24}$ kepada OJK. Di sisi lain, pihak OJK juga melakukan persiapan meliputi: penerimaan Pernyataan Pendaftaran; ekspose terbatas di OJK; evaluasi oleh OJK; komentar tertulis; hingga Pernyataan Pendaftaran dinyatakan efektif.

2. Penawaran Umum (untuk pasar perdana)
a. Pengumuman dan pendistribusian prospektus.
b. Penawaran Efek oleh penjamin emisi dan agen penjual.
c. Pemesanan Efek.
d. Penjatahan Efek.
e. Pengembalian dana.
f. Penyerahan Efek.

3. Pasca Penawaran Umum

a. Laporan berkala.

b. Laporan insidentil.

Dengan hadirnya POJK 41/2020, maka tahapan kedua terkait Penawaran Umum tersebut di atas, yang awalnya manual, dialihkan pelaksanaannya ke dalam Sistem e-IPO.

Proses Penawaran Umum secara elektronik dimulai setelah Pernyataan Pendaftaran dinyatakan efektif oleh OJK. Setelah Pernyataan Pendaftaran efektif,

23 Mas Rahmah, supra no. 2, hlm. 156-157.

24 Pernyataan Pendaftaran adalah dokumen yang wajib disampaikan kepada OJK oleh Emiten dalam rangka Penawaran Umum atau Perusahaan Publik (Pasal 1 angka 10 POJK 41/2020). 
Emiten (melalui Partisipan Admin ${ }^{25}$ ) melakukan pengumuman mengenai Penawaran Umum melalui Sistem e-IPO. Emiten memiliki kewajiban untuk melakukan penginputan data/informasi yang disyaratkan dan pengunggahan dokumen pada Sistem e-IPO. Selain pengumuman melalui Sistem e-IPO, Emiten juga berkewajiban melakukan pengumuman melalui surat kabar nasional. Masa penawaran Efek akan dilaksanakan paling singkat selama 3 (tiga) hari kerja dan paling lama 5 (lima) hari kerja.

Bagi pemodal yang berminat untuk melakukan pembelian Efek dalam proses Penawaran Umum secara elektronik dapat menyampaikan minat dan/atau pemesanan atas Efek yang ditawarkan melalui Sistem e-IPO pada masa Penawaran Awal (untuk minat) atau masa penawaran Efek (untuk pemesanan). Pemodal dapat melakukan perubahan maupun pembatalan pemesanan atas Efek hanya selama masa penawaran Efek. Pemesanan Efek dalam Penawaran Umum melalui Sistem e-IPO, wajib disertai dengan ketersediaan dana yang cukup dari pemodal. Dalam hal dana pemodal yang tersedia tidak mencukupi, maka pesanan hanya akan dipenuhi sesuai dengan jumlah dana yang tersedia, dengan kelipatan sesuai satuan perdagangan Bursa Efek.

Pengalokasian Penjatahan Pasti ${ }^{26}$ atas Efek akan dilakukan oleh Partisipan Admin. Dalam hal ini, Penjamin Emisi Efek berhak untuk menentukan dan/atau melakukan penyesuaian terhadap pesanan pemodal dalam Penjatahan Pasti. Proses input alokasi ke Sistem e-IPO dilakukan selama masa penawaran Efek. Berkaitan dengan alokasi Efek, Emiten memiliki kewajiban untuk mengalokasikan sejumlah tertentu Efek untuk Penjatahan Terpusat ${ }^{27}$ sesuai dengan golongan Penawaran Umum. Dari alokasi untuk Penjatahan Terpusat tersebut wajib

25 Partisipan Admin adalah Partisipan Admin yang memiliki izin sebagai Penjamin Emisi Efek dan ditunjuk oleh Emiten sebagai pihak yang bertanggung jawab atas penggunaan Sistem eIPO (Pasal 1 angka 8 POJK 41/2020).

26 Penjatahan Pasti adalah mekanisme penjatahan Efek yang dilakukan dengan cara memberikan alokasi efek kepada pemesan sesuai dengan jumlah pesanan Efek (Pasal 1 angka 22 POJK 41/2020).

27 Penjatahan Terpusat adalah mekanisme penjatahan efek yang dilakukan dengan cara mengumpulkan seluruh pemesanan Efek dan kemudian dijatahkan sesuai prosedur (Pasal 1 angka 23 POJK 41/2020). 
dialokasikan untuk Penjatahan Terpusat Ritel (merupakan penjatahan untuk Pemesan Ritel ${ }^{28}$ ).

Proses penyelesaian pemesanan efek dilaksanakan setelah diterbitkannya hasil penjatahan efek dan paling lambat sebelum pencatatan efek di Bursa Efek. Penyelesaian pemesanan Efek yang ditawarkan mencakup kegiatan penyelesaian pembayaran atas Efek yang dipesan oleh pemodal, dan distribusi Efek sesuai hasil penjatahan. Ketentuan lebih lanjut mengenai penggolongan Penawaran Umum, batasan dan penyesuaian alokasi Efek untuk Penjatahan Terpusat, serta penyelesaian pemesanan efek diatur dalam Surat Edaran Otoritas Jasa Keuangan Republik Indonesia Nomor 15/SEOJK.04/2020 tentang Penyediaan Dana Pesanan, Verifikasi Ketersediaan Dana, Alokasi Efek untuk Penjatahan Terpusat, dan Penyelesaian Pemesanan Efek dalam Penawaran Umum Efek Bersifat Ekuitas Berupa Saham secara Elektronik (selanjutnya disebut "SEOJK 15/2020").

Seperti dijelaskan sebelumnya, bahwa Sistem e-IPO juga harus menghasilkan laporan terkait kegiatan Penawaran Umum. Adapun laporan tersebut paling sedikit memuat tentang hasil pelaksanaan Penawaran Awal, hasil Penawaran Umum, Penjatahan, dan distribusi Efek. Pihak yang dapat memperoleh laporan yang dihasilkan Sistem e-IPO adalah OJK, Penyedia Sistem, Partisipan Sistem, dan Partisipan Admin, sesuai dengan kewenangannya dalam kegiatan Penawaran Umum, serta pihak lain (dengan persetujuan OJK).

OJK mengatur bahwa ketentuan penggunaan Sistem e-IPO bagi Penawaran Umum efek bersifat ekuitas berupa saham, akan mulai berlaku bagi Emiten yang menyampaikan Pernyataan Pendaftaran kepada OJK setelah 6 (enam) bulan POJK 41/2020 ini mulai berlaku. Atau lebih tepatnya berlaku pada awal Januari 2021. Sedangkan pemberlakuan ketentuan kewajiban penggunaan Sistem untuk Penawaran Umum selain Penawaran Umum Efek berupa ekuitas berupa saham akan ditetapkan lebih lanjut oleh OJK.

Bahwa kehadiran Sistem e-IPO dirasa akan memberikan kemudahan kepada pemodal (baik pemodal besar maupun pemodal kecil dan menengah)

28 Pemesan Ritel adalah pihak yang menyampaikan minat dan/atau pesanan atas Efek yang akan ditawarkan dengan nilai paling banyak Rp.100.000.000,00 (Pasal 1 angka 21 POJK 41/2020). 
untuk melakukan investasi di pasar modal. Hal tersebut dikarenakan semua informasi dan proses Penawaran Umum dilakukan dalam satu wadah yaitu Sistem e-IPO, sehingga para pemodal tidak perlu mencari informasi di tempat lain. Para pemodal akan mendapatkan informasi penentuan harga penawaran dan jumlah efek yang ditawarkan lebih transparan, sehingga dapat meningkatkan kepercayaan para pemodal terhadap investasi yang akan dipilih.

Dalam Sistem e-IPO pemodal publik juga diberikan kemudahan untuk melakukan pemesanan Efek untuk alokasi Efek Penjatahan Terpusat. Umumnya proses bisnis Penawaran Umum untuk Penjatahan Terpusat relatif sulit karena dilakukan secara manual melalui gerai pemesanan. Namun dengan Sistem e-IPO, maka pemesanan dapat dilakukan melalui Sistem e-IPO tanpa perlu ke gerai tersebut. Sistem e-IPO juga memberikan kepastian bagi Pemesan Ritel untuk mendapatkan alokasi Efek dalam Penjatahan Terpusat.

\section{Perlindungan Hukum bagi Pemodal dalam Sistem Penawaran Umum Elektronik Berdasarkan POJK 41/2020}

Pasar modal sebagai instrumen keuangan hanya dapat berkembang dengan baik apabila dibangun berdasarkan prinsip wajar, transparan, dan aman. ${ }^{29}$ Ketiga prinsip tersebut memiliki peran penting untuk melindungi kepentingan dari pemodal yang berujung pada membangun kepercayaan pemodal tersebut. Pemodal merupakan pihak penting yang menggerakkan dan mengembangkan pasar modal. Kegiatan dalam pasar modal dilandasi dengan rasa percaya para pemodal terhadap pihak atau lembaga yang berperan menjalankan kegiatan pasar modal. Salah satu cara meningkatkan kepercayaan pemodal adalah dengan memberikan jaminan dan perlindungan terhadap pemodal maupun investasinya di sektor pasar modal. Perlindungan tersebut dapat berupa jaminan bahwa hukum akan melindungi pemodal untuk dapat melaksanakan investasinya dengan aman, memiliki kedudukan yang sama dengan pemodal yang lain, atau mendapatkan akses informasi yang transparan terkait kegiatan pasar modal sesuai dengan

29 Indra Safitri, Peranan Hukum Pasar Modal dalam Perkembangan Ekonomi Indonesia, Jurnal Legislasi Indonesia, Vol. 5 No. 2, Juni 2008, hlm. 1. 
kebutuhan pemodal. Oleh karena itu perlindungan hukum bagi pemodal di sektor pasar modal merupakan hal yang penting dalam meningkatkan kepercayaan pemodal untuk melakukan investasi di sektor pasar modal.

Begitu juga dengan kegiatan Penawaran Umum menggunakan Sistem eIPO. Sebagai sebuah sistem baru di sektor pasar modal maka Sistem e-IPO juga perlu mendapatkan kepercayaan dari masyarakat atau pemodal untuk dapat menarik minat mereka. Selain memberi kemudahan dalam mengakses Penawaran Umum, Sistem e-IPO juga harus memberi jaminan rasa aman bagi pemodal yang menginvestasikan dananya. Oleh karena itu, Sistem e-IPO juga harus menawarkan perlindungan hukum bagi para pemodal yang terlibat di dalamnya.

Demi terciptanya kepastian hukum, maka sewajarnya perlindungan hukum bagi pemodal dituangkan dalam peraturan perundang-undangan yang mengatur Sistem e-IPO, yaitu POJK 41/2020. Perlindungan hukum sendiri memiliki pengertian sebagai segala bentuk norma maupun tindakan yang bertujuan untuk memberikan kondisi aman, nyaman, dan kepastian hukum bagi subyek hukum baik orang perorangan maupun badan hukum. Dengan adanya perlindungan hukum diharapkan dapat menghindari persengketaan, dan seandainya terjadi sengketa-pun, telah terdapat norma hukum untuk penyelesaiannya. ${ }^{30}$

Berkaitan dengan perlindungan hukum, menurut R. La Porta dalam Journal of Financial Economics, perlindungan hukum yang diberikan suatu negara memiliki dua sifat, yaitu bersifat pencegahan (prohibited) dan bersifat hukuman (sanction). ${ }^{31}$ Perlindungan hukum bersifat pencegahan dikenal dengan perlindungan hukum preventif, sedangkan perlindungan hukum yang bersifat hukuman dikenal juga dengan perlindungan hukum represif. Mengacu kepada dua sifat perlindungan hukum tersebut, maka penulis bermaksud menelaah bentuk perlindungan hukum yang diberikan oleh POJK 41/2020 kepada pemodal dalam pelaksanaan Sistem e-IPO.

30 Philipus M Hadjon, Perlindungan Hukum Bagi Rakyat di Indonesia, Bina Ilmu, Surabaya, 1987, hlm. 1.

31 Hilda Hilmiyah Dimyati, Perlindungan Hukum Bagi Investor dalam Pasar Modal, Jurnal Cita Hukum Vo. II No. 2 Desember 2014, Fakultas Syariah dan Hukum Universitas Islam Negeri Syarif Hidayatullah Jakarta. 
Perlindungan hukum yang bersifat preventif pada umumnya merupakan peraturan atau norma hukum yang sifatnya mencegah terjadinya pelanggaran hukum. Dalam POJK 41/2020, perlindungan hukum khususnya bagi pemodal, yang bersifat preventif terlihat dalam beberapa ketentuan sebagai berikut:

1. Kewajiban Penyedia Sistem memiliki dan menetapkan standar prosedur operasional. ${ }^{32}$ Ketentuan ini bertujuan agar Sistem e-IPO wajib memiliki dan dijalankan sesuai prosedur oleh para pihak yang memiliki akses untuk mengoperasikan Sistem e-IPO. Prosedur ini akan mencegah para pihak tersebut untuk bertindak sewenang-wenang dalam mengoperasikan Sistem e-IPO, yang dapat menimbulkan kerugian bagi pemodal maupun pihak lain dalam Sistem e-IPO. Selain melindungi pemodal dan kelancaran Sistem eIPO, ketentuan ini juga meningkatkan kredibilitas Sistem e-IPO di mata pemodal. Karena umumnya sebuah sistem yang memiliki dan menetapkan prosedur yang baik dalam pelaksanaannya lebih dipercaya penggunanya.

2. Kewajiban bagi Penyedia Sistem untuk menerapkan prinsip pengendalian dan keamanan yang memadai dalam Sistem e-IPO. ${ }^{33}$ Bahwa dalam Sistem eIPO harus diterapkan prinsip pengendalian dan prinsip pengamanan yang memadai, sesuai peraturan perundang-undangan di Indonesia dan/atau standar yang berlaku secara nasional maupun internasional. Ketentuan ini bertujuan agar Sistem e-IPO dapat beroperasi dengan baik, aman, serta kerahasiaan data dan informasi khususnya milik pemodal dapat terjaga sesuai dengan standar keamanan sistem teknologi informasi pada sektor pasar modal di Indonesia. Ketentuan ini dapat menjaga kepercayaan pemodal bahwa Sistem e-IPO menerapkan sistem pengendalian dan keamanan yang baik.

3. Kewajiban Penyedia Sistem untuk menginformasikan kepada pengguna Sistem e-IPO dalam hal terdapat perubahan atau pengembangan sistem, termasuk dalam hal terdapat penambahan layanan dan fitur dalam Sistem e-

32 Peraturan Otoritas Jasa Keuangan Nomor 41/POJK.04/2020 tentang Pelaksanaan Kegiatan Penawaran Umum Efek Bersifat Ekuitas, Efek Bersifat Utang, dan/atau Sukuk secara Elektronik Pasal 2 ayat (3) huruf c.

33 Id., Pasal 2 ayat (3) huruf e. 
IPO. ${ }^{34}$ Ketentuan ini bertujuan agar pengguna Sistem e-IPO, khususnya pemodal tidak mengalami kebingungan dalam hal terjadi perubahan dalam Sistem e-IPO, dan pemodal dapat mengetahui perkembangan terbaru dari Sistem e-IPO. Informasi ini juga membuat pemodal mengetahui bahwa perubahan yang terjadi dalam Sistem e-IPO mungkin mengakibatkan Sistem e-IPO tidak berfungsi sebagaimana mestinya. Dalam hal ini Penyedia Sistem tidak dapat sewenang-wenang dalam melakukan perubahan atau pengembangan dalam Sistem e-IPO yang akhirnya dapat menimbulkan kesulitan atau kerugian bagi pemodal.

4. Kewajiban Penyedia Sistem untuk menyediakan rekam jejak audit terhadap keseluruhan proses di Sistem e-IPO untuk keperluan pengawasan, penegakkan hukum, penyelesaian sengketa, verifikasi, pengujian, dan pemeriksaan lainnya oleh $\mathrm{OJK}$ atau pihak lain dengan persetujuan OJK. ${ }^{35}$ Bahwa rekam jejak audit keseluruhan proses dalam Sistem e-IPO merupakan hal penting. Berdasarkan rekam jejak tersebut, maka akan terlihat proses pelaksanaan Sistem e-IPO, apakah telah sesuai dengan prosedur atau ketentuan yang berlaku, ataukah tidak. Sehingga dalam hal pemodal atau pengguna Sistem e-IPO mengalami permasalahan atau merasa dirugikan pada saat penggunaan Sistem e-IPO, maka pihak OJK dapat melakukan pemeriksaan berdasarkan rekam jejak audit.

5. Kewajiban Penyedia Sistem untuk menjaga kerahasiaan data dan informasi pengguna serta penggunaan Sistem e-IPO. ${ }^{36}$ Dengan adanya ketentuan ini maka pemodal dan pengguna Sistem e-IPO memiliki jaminan bahwa data, informasi dan segala bentuk transaksi yang dilakukan dalam Sistem e-IPO akan dilindungi kerahasiaannya serta tidak dipergunakan secara sewenangwenang.

6. Kewajiban Penyedia Sistem untuk memiliki dan menetapkan fasilitas pengganti pusat data dan pusat pemulihan bencana terkait penyelenggaraan

\footnotetext{
Id., Pasal 2 ayat (3) huruf f.

Id., Pasal 2 ayat (3) huruf g. Id., Pasal 2 ayat (3) huruf h.
} 
Sistem e-IPO di wilayah Indonesia pada tempat yang aman dan terpisah dari pusat data utama. ${ }^{37}$ Dengan adanya ketentuan ini, maka segala data yang terdapat dalam Sistem e-IPO dijamin memiliki cadangan atau back up dalam hal pusat data utama mengalami kerusakan, kehilangan data, atau hal lain yang mengakibatkan pusat data utama tidak berfungsi sebagaimana mestinya. Hal ini memberikan jaminan kepada pemodal bahwa kegiatan dalam Sistem e-IPO tetap dapat berjalan meskipun terdapat permasalahan dalam pusat data utama.

7. Kewajiban Emiten untuk melakukan pengumuman terhadap penundaan atau pembatalan Penawaran Umum. ${ }^{38}$ Pengumuman ini harus dilakukan Emiten pada Sistem e-IPO dan surat kabar nasional berbahasa Indonesia. Ketentuan ini mencegah Emiten untuk bertindak sewenang-wenang dalam merubah atau membatalkan jadwal Penawaran Umum, yang mana hal tersebut merugikan pemodal.

8. Kewajiban verifikasi terhadap minat dan/atau pesanan pemodal. ${ }^{39}$ Bahwa setiap minat dan/atau pesanan pemodal atas Efek yang ditawarkan wajib untuk diverifikasi ulang untuk memeriksa kesesuaian identitas dari pemodal, rekening pemodal, maupun jumlah Efek yang diminati dan/atau dipesan pemodal. Kewajiban ini sebagai bentuk kehati-hatian dalam pelaksanaan Penawaran Umum dalam hal data atau informasi dalam penyampaian minat dan/atau pesanan ternyata tidak sesuai.

9. Dalam Sistem e-IPO, pemodal harus menyatakan bahwa telah menerima atau telah memperoleh kesempatan untuk membaca Prospektus berkenaan dengan Efek yang ditawarkan sebelum atau pada saat melakukan pemesanan. ${ }^{40}$ Bahwa Prospektus merupakan informasi yang diperlukan pemodal untuk membuat keputusan akan membeli atau tidak Efek yang ditawarkan. Oleh karena itu pemodal harus mengetahui dan memahami

\footnotetext{
Id., Pasal 2 ayat (3) huruf l.

Id., Pasal 16.

Id., Pasal 23.

Id., Pasal 28.
} 
informasi dalam Prospektus. Hal ini mencegah pemodal untuk mengalami kerugian dalam melakukan investasi yang salah.

10. Pemodal diberi kesempatan untuk melakukan konfirmasi dalam hal pada akhir masa Penawaran Awal harga Efek yang disampaikan pada saat penyampaian minat oleh pemodal sama dengan atau lebih tinggi dari harga penawaran Efek yang ditetapkan. ${ }^{41}$ Perlu diketahui bahwa dalam Penawaran Awal Efek ada rentang harga, maka ada kalanya minat atas harga Efek yang disampaikan pemodal berbeda dengan harga akhir penawaran Efek. Untuk mencegah pemodal melakukan pembelian Efek dengan harga yang tidak diminati, maka perlu adanya konfirmasi ulang kepada pemodal. Berkaitan dengan rentang harga, POJK 41/2020 juga mengamanatkan Emiten untuk memberikan informasi dalam Sistem e-IPO dalam hal selama Penawaran Awal terdapat perubahan terhadap rentang harga. ${ }^{42}$

11. Apabila penetapan harga dan jumlah Efek yang ditawarkan berada di luar kurva permintaan Penawaran Awal yang dihasilkan oleh Sistem e-IPO, maka Emiten wajib mengungkapkan penjelasan atas pertimbangan penetapan harga dan jumlah Efek yang ditawarkan tersebut dalam Prospektus. ${ }^{43}$ Perlu diketahui bahwa kurva permintaan adalah akumulasi minat pada masingmasing harga dalam rentang harga Penawaran Awal. Kewajiban memberikan penjelasan ini akan membantu pemodal dalam membuat keputusan, serta meningkatkan transparansi dalam Sistem e-IPO.

12. Alokasi Efek untuk Penjatahan Terpusat Ritel. ${ }^{44}$ Adanya alokasi untuk Penjatahan Terpusat Ritel memberikan kepastian bahwa para pemodal yang merupakan Pemesan Ritel mendapatkan alokasi untuk melakukan pembelian atas Efek yang ditawarkan dalam Penawaran Umum.

13. Dalam hal terjadi kegagalan Sistem e-IPO, Penyedia Sistem dapat melakukan penyesuaian jangka waktu kegiatan dalam Penawaran Umum atau tindakan
Id., Pasal 29.
Id., Pasal 35.
Id., Pasal 37.
Id., Pasal 38 ayat (2). 
lainnya untuk penyelesaian kegiatan Penawaran Umum. ${ }^{45}$ Serta dalam hal terjadi suatu keadaan lain di luar kemampuan dan kekuasaan Penyedia Sistem (bencana dan peristiwa lain yang berpengaruh secara signifikan terhadap pelaksanaan Penawaran Umum), maka Penyedia Sistem dapat melakukan penyesuaian jangka waktu kegiatan dalam Penawaran Umum atau tindakan lainnya untuk penyelesaian kegiatan Penawaran Umum dengan persetujuan 0JK.46 Adanya dua ketentuan tersebut memberikan jaminan bagi para pemodal bahwa meskipun terjadi kegagalan sistem maupun hal lain yang mempengaruhi Penawaran Umum dalam Sistem e-IPO, hak pemodal untuk melaksanakan Penawaran Umum dan mendapatkan Efek yang diinginkan tetap terpenuhi, meski memerlukan waktu penyesuaian.

Selain perlindungan hukum yang bersifat preventif, POJK 41/2020 juga menyediakan perlindungan hukum yang bersifat represif. Perlindungan hukum yang bersifat represif merupakan peraturan atau norma hukum yang sifatnya menyelesaikan permasalahan hukum yang terjadi. Perlindungan hukum ini umumnya berupa sanksi dalam bentuk denda, hukuman penjara atau hukuman lainnya. POJK 41/2020 memberikan perlindungan hukum yang bersifat represif dalam bentuk sanksi administratif bagi pelanggar ketentuan dalam POJK 41/2020. Sanksi administratif POJK 41/2020 tidak hanya dikenakan kepada pihak yang melakukan pelanggaran ketentuan POJK 41/2020, namun juga kepada pihak yang menjadi penyebab terjadinya pelanggaran tersebut. Adapun pihak yang berwenang untuk memberikan sanksi administratif adalah 0JK, setelah OJK memastikan bahwa pihak tersebut memang melakukan pelanggaran terhadap ketentuan POJK 41/2020.

Bentuk sanksi administratif yang dikenakan OJK kepada pelanggar POJK 41/2020 berupa: a) peringatan tertulis; b) denda, yaitu kewajiban untuk membayar sejumlah uang tertentu; c) pembatasan kegiatan usaha; d) pembekuan kegiatan usaha; e) pencabutan izin usaha; f) pembatalan persetujuan; dan g)

45 Id., Pasal 54 ayat (1).

46 Id., Pasal 54 ayat (2). 
pembatalan pendaftaran. ${ }^{47}$ Penerapan sanksi huruf b hingga g tersebut dapat dilaksanakan tanpa pelanggar dikenakan sanksi peringatan tertulis terlebih dahulu. Ketentuan tentang sanksi denda juga dapat dikenakan secara terpisah maupun bersama-sama dengan sanksi lainnya. Selain bentuk sanksi administratif tersebut, OJK juga dapat melakukan tindakan lain terhadap pelanggar ketentuan POJK 41/2020. Tindakan lain tersebut dapat berupa penundaan pelaksanaan Penawaran Umum maupun pembatalan proses Penawaran Umum.

Perlu dipahami bahwa perlindungan hukum terhadap transaksi Penawaran Umum melalui Sistem e-IPO tidak berhenti hanya sebagaimana diatur dalam POJK 41/2020. Perlindungan hukum di sektor pasar modal mengacu pada semua ketentuan hukum yang berlaku termasuk namun tidak terbatas sebagaimana diatur dalam UUPM beserta dengan peraturan pelaksanaannya.

Dalam UUPM contohnya, UUPM menganut prinsip keterbukaan di sektor Pasar Modal. Keterbukaan informasi wajib dilakukan dan harus dijamin kebenarannya sehingga pemodal dapat memahami keadaan perusahaan Emiten sebelum mengambil keputusan untuk membeli efek atau tidak. ${ }^{48}$ Prinsip keterbukaan merupakan salah satu perlindungan hukum yang diberikan oleh UUPM kepada para pemodal.

Di sisi lain, OJK sebagai lembaga yang bertugas menegakkan perlindungan konsumen jasa keuangan, juga memberikan perlindungan terhadap pemodal selaku konsumen di sektor pasar modal. Hal tersebut sebagaimana diatur dalam Pasal 28, Pasal 29, dan Pasal 30 UUOJK yang merupakan ketentuan-ketentuan yang mengatur secara eksplisit perihal perlindungan konsumen. Perlindungan konsumen sektor jasa keuangan di rezim OJK menaungi seluruh sektor jasa keuangan meliputi lembaga keuangan bank maupun non-bank. Penyatuan

Id., Pasal 55 ayat (4).

48 Zaenah, Aspek Hukum dalam Penerapan Prinsip Full Disclosure di Pasar Modal, Lex Journal: Kajian Hukum dan Keadilan Vol. 1 No. 2 Tahun 2017, Fakultas Hukum Universitas Dr. Soetomo Surabaya. 
pengaturan perlindungan konsumen jasa keuangan yang selama ini terpencar dimaksudkan untuk memperbaiki sistem dan menutup kekurangan substansial. ${ }^{49}$

Karena pemodal merupakan konsumen di sektor pasar modal, maka pemodal juga dilindungi oleh UU Nomor 8 Tahun 1999 tentang Perlindungan Konsumen beserta peraturan pelaksanaannya. Selain itu, mengingat bahwa Penawaran Umum secara Elektronik merupakan transaksi penawaran saham yang dilakukan dengan menggunakan teknologi informasi dan sebuah sistem elektronik, maka wajar bila perlindungan hukumnya juga diatur dalam UU Nomor 11 Tahun 2008 tentang Informasi dan Transaksi Elektronik j.o. UU Nomor 19 Tahun 2016 tentang Perubahan UU Nomor 11 Tahun 2008 tentang Informasi dan Transaksi Elektronik. Berdasarkan hal-hal tersebut, terkait perlindungan hukum Penawaran Umum melalui Sistem e-IPO yang tidak diatur dalam POJK 41/2020, maka perlu untuk melihat kembali pada aturan hukum lain yang berhubungan dengan Penawaran Umum tersebut.

\section{Penutup}

Sistem Penawaran Umum secara elektronik hadir sebagai terobosan baru dengan tujuan menarik minat pemodal. Demi tercapainya kepastian hukum, maka OJK menetapkan POJK 41/2020. POJK tersebut dibuat berdasarkan kewenangan yang dimiliki OJK yang didapat melalui UUOJK dan UUPM. Oleh karena itu POJK 41/2020 memiliki kedudukan kuat sebagai dasar hukum pelaksanaan Penawaran Umum melalui Sistem e-IPO.

Bahwa pelaksanaan Penawaran Umum melalui Sistem e-IPO merupakan bentuk sistemisasi proses Penawaran Umum yang sebelumnya dilakukan secara manual. Dengan sistemisasi ini diharapkan pemodal lebih mudah mengakses, mendapatkan informasi, dan mendapatkan alokasi Efek dalam kegiatan Penawaran Umum. Sistem e-IPO menjadi pemeran utama dalam Penawaran Umum secara elektronik. Sistem e-IPO mencakup kegiatan Penawaran Awal,

49 Vidya Noor Rachmadini, Perlindungan Hukum bagi Investor dalam Pasar Modal menurut Undang-Undang Pasar Modal dan Undang-Undang Otoritas Jasa Keuangan, Pena Justitia: Media Komunikasi dan Kajian Hukum Vol. 18, No. 1 Tahun 2019, Fakultas Hukum Universitas Pekalongan, hlm. 93. 
penawaran Efek, penjatahan Efek, dan penyelesaian pemesanan atas Efek yang ditawarkan.

Perbedaan Penawaran Umum Sistem e-IPO dengan Penawaran Umum biasa adalah penggunaan sistem yang menjadi wadah satu pintu bagi pemodal untuk melakukan pembelian Efek. Adanya fungsi baru seperti Penyedia Sistem, Partisipan Sistem, atau Partisipan Admin juga menjadi pembeda bagi Sistem eIPO. Dengan adanya fungsi-fungsi baru serta penggabungan beberapa pihak sebagai Penyedia Sistem, maka menurut penulis perlu adanya koordinasi para pihak dengan OJK sebagai pengawas utama. Hal ini akan menjadi tantangan baru bagi OJK untuk dapat menciptakan harmonisasi dari para pihak yang tergabung dalam Sistem e-IPO.

POJK 41/2020 berusaha agar pemodal tidak mengalami kerugian berkaitan dengan kesalahan informasi, kebocoran data, kegagalan sistem, maupun kesalahan proses dalam Sistem e-IPO. POJK 41/2020 juga menerapkan sanksi administratif bagi pihak yang melakukan pelanggaran terhadap ketentuan POJK $41 / 2020$, hal tersebut sebagai bentuk perlindungan hukum bagi para pemodal. Namun perlu diingat kembali, bahwa dalam penerapannya POJK 41/2020 tidak dapat berdiri sendiri dalam memberikan perlindungan hukum kepada pemodal. POJK 41/2020 masih bergantung pada peraturan perundang-undangan di atasnya termasuk namun tidak terbatas pada UUPM, UUOJK, UU Informasi dan Transaksi Elektronik, dan UU Perlindungan Konsumen. 


\section{Daftar Pustaka}

\section{Buku:}

Andrian Sutedi, Aspek Hukum Otoritas Jasa Keuangan, Raih Asa Sukses, Jakarta, 2014.

Mas Rahmah, Hukum Pasar Modal, Kencana, Jakarta, 2019

Philipus M. Hadjon, Perlindungan Hukum Bagi Rakyat di Indonesia, Bina Ilmu, Surabaya, 1987

Peter Mahmud Marzuki, Penelitian Hukum (Edisi Revisi), Kencana, Jakarta, 2015

Sunariyah, Pengantar Pengetahuan Pasar Modal, UPP AMP YKPN, Yogyakarta, 2011

\section{Jurnal:}

Hilda Hilmiyah Dimyati. Perlindungan Hukum bagi Investor dalam Pasar Modal. Jurnal Cita Hukum Vol. II No. 2, Desember 2014. Jakarta: Fakultas Syariah dan Hukum Universitas Islam Negeri Syarif Hidayatullah.

Indra Safitri. Peranan Hukum Pasar Modal dalam Perkembangan Ekonomi Indonesia. Jurnal Legislasi Indonesia, Vol. 5 No. 2, Juni 2008.

Rochani Urip Salami. Hukum Pasar Modal dan Tanggung Jawab Sosial. Jurnal Dinamika Hukum Vol. 11 No. 3, September 2011. Fakultas Hukum Universitas Jenderal Soedirman.

Vidya Noor Rachmadini. Perlindungan Hukum bagi Investor dalam Pasar Modal menurut Undang-Undang Pasar Modal dan Undang-Undang Otoritas Jasa Keuangan. Jurnal Pena Justitia: Media Komunikasi dan Kajian Hukum Vol. 18, No. 1 Tahun 2019. Fakultas Hukum Universitas Pekalongan.

Zaenah. Aspek Hukum dalam Penerapan Prinsip Full Disclosure di Pasar Modal. Lex Journal: Kajian Hukum dan Keadilan Vol. 1 No. 2 Tahun 2017. Fakultas Hukum Universitas Dr. Soetomo Surabaya.

\section{Peraturan Perundang-undangan:}

Undang-Undang Republik Indonesia Nomor 8 Tahun 1995 tentang Pasar Modal.

Undang-Undang Republik Indonesia Nomor 12 Tahun 2011 tentang Pembentukan Peraturan Perundang-Undangan.

Undang-Undang Republik Indonesia Nomor 21 Tahun 2011 tentang Otoritas Jasa Keuangan.

Peraturan Otoritas Jasa Keuangan Nomor 41/POJK.04/2020 tentang Pelaksanaan Kegiatan Penawaran Umum Efek Bersifat Ekuitas, Efek Bersifat Utang, dan/atau Sukuk secara Elektronik.

Surat Edaran Otoritas Jasa Keuangan Republik Indonesia Nomor 15/SEOJK.04/2020 tentang Penyediaan Dana Pesanan, Verifikasi Ketersediaan Dana, Alokasi Efek untuk Penjatahan Terpusat, dan Penyelesaian Pemesanan Efek dalam Penawaran Umum Efek Bersifat Ekuitas Berupa Saham secara Elektronik. 


\section{Lain-lain:}

Ringkasan Peraturan Otoritas Jasa Keuangan Nomor 41/P0JK.04/2020 tentang Pelaksanaan Kegiatan Penawaran Umum Efek Bersifat Ekuitas, Efek Bersifat Utang, dan/atau Sukuk secara Elektronik.

Surat Keputusan Direksi PT Bursa Efek Indonesia No. Kep-00051/BEI/08-2020 perihal Pedoman Partisipan Sistem dalam Menggunakan Sistem Electronic Indonesia Public Offering yang Disediakan oleh PT Bursa Efek Indonesia.

\section{Internet:}

https://www.cnbcindonesia.com/market/20200807124040-17-

178199/ternyata-ini-yang-jadi-penyebab-pasar-modal-ri-kian-stabil

https://www.idx.co.id/berita/press-release-detail/?emitenCode $=1344$

https://www.e-ipo.co.id/id

https://www.idx.co.id/

https://www.idx.co.id/footer-menu/tautan-langsung/daftar-istilah/\#glossaryE, 